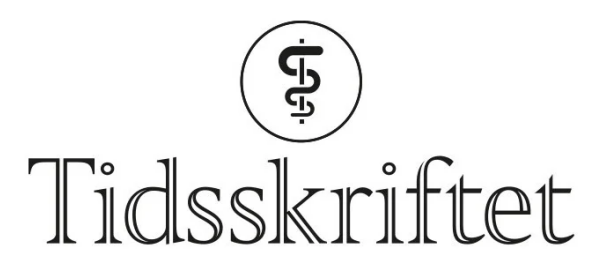

DEN NORSKE LEGEFORENING

\title{
Nordens beste lærebok i fødselshjelp
}

\author{
ANMELDELSER
}

\section{BJØRN BACKE}

Kvinneklinikken

St. Olavs hospital

Trondheim

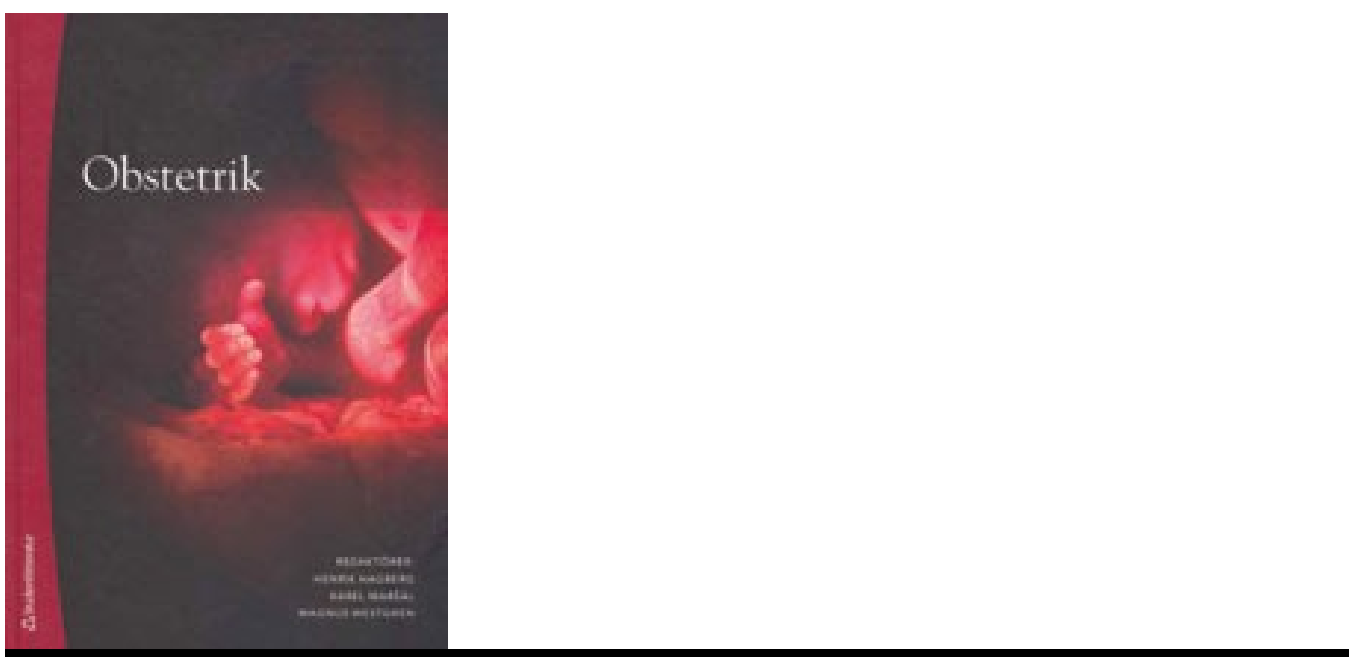

Hagberg, $\mathrm{H}$

Marsál, K

Westberg, M

Obstetrik

768 s, tab, ill. Lund: Studentlitteratur, 2008. Pris SEK 828

ISBN 978-91-44-00731-1

Etter mange år kom det i 2008 en ny svensk lærebok i fødselshjelp. Den er omfattende, med 65 kapitler skrevet av kjente svenske eksperter. Det svenske fagmiljøet er stort og tungt, og flere av forfatterne er internasjonale toppeksperter. Alene er det nok til å gjøre dette til en interessant utgivelse.

Layouten er meget oversiktlig og tiltalende og rikt illustrert med mange fargebilder. Spesielt er de skjematiske tegningene meget instruktive. 
Målgruppen er ifølge forordet de under lege- og jordmorutdanning, men redaktørene håper også at boken skal anvendes som referanselitteratur innen svangerskapsomsorg, fødselshjelp og perinatalomsorg. Dette er en ambisiøs målsetting.

Boken er, rimeligvis, skrevet på svensk - for svensker. Typiske svenske uttrykk er brukt i rikelig grad, som f.eks. «snedklipp», «vidöppen bjudning» og "framstupa bjudning». Dersom de latinske begrepene «episiotomi», «occiput posterior-presentasjon» og «occiput anterior-presentasjon» hadde vært tilføyd, hadde boken vært lettere tilgjengelig for nordiske lesere. Når fosteret ligger med ryggen til venstre, vil resten av verden si nettopp det, men i Sverige er fosteret «högervendt». Det tar ikke lang tid før man skjønner hva «snedklipp i mellangården» er. Kanskje må man gruble litt over at «barnafödersken skal ha en kilkudde under höger klinka» når man setter paracervikalbedøvelse.

Det er oppgitt referanser etter hvert kapittel, men ikke i teksten. Oftest er det originallitteratur eller større lærebøker som refereres, og man må lete lenge i litteraturlistene for å finne kunnskapsoppsummeringer. Det er litt overraskende at boken ikke bekjenner seg til den kunnskapsbaserte tradisjonen. Det kan virke som om de fleste kapittelforfatterne skriver i prosedyretradisjonen. De forklarer hvordan ting skal gjøres ofte uten begrunnelse og uten diskusjon. Det står f.eks. - uten reservasjon - at man alltid skal gjøre innkomst-CTG og deretter, hvis alt er i orden, fortsette med intermitterende CTG samt kontinuerlig CTG i utdrivningstiden.

Kapitlene er litt ujevne, men de fleste er riktig bra. Spesielt bra er kapitlene som går på fysiologi. Tangforløsning har lenge vært en sjeldenhet i Sverige, og det er kanskje derfor de instrumentene som omtales er Wrigleys tang og Naegeles tang, tangmodeller som mange vil hevde er historiske.

Innholdsmessig faller nok boken mellom flere stoler. Etter min mening er den altfor omfattende som pensumbok for jordmorstudenter og medisinstudenter.

Spesialistkandidater kan godt lese den fra perm til perm i starten av utdanningen, men de bør skaffe seg mer omfattende oppslagsverk. Som oppslagsverk på fødeavdelinger egner den seg godt og kan anbefales. Dette er utvilsomt den beste og mest omfattende nordiske læreboken i fødselshjelp.

Publisert: 28. mai 2009. Tidsskr Nor Legeforen. DOI:10.4045/tidsskr.09.0404

(C) Tidsskrift for Den norske legeforening 2023. Lastet ned fra tidsskriftet.no 26. april 2023. 